Türkiye Tarımsal Araştırmalar Dergisi
http://dergi.siirt.edu.tr/index.php/ziraat $\begin{aligned} & \text { Turk J Agric Res } \\ & \text { (2014) 1: 117-127 } \\ & \text { TÜTAD } \\ & \text { ISSN: 2148-2306 }\end{aligned}$

\title{
Diyarbakır Ekolojik Koşullarında Bazı Yaygın Fiğ (Vicia sativa L.) Genotiplerinin Verim ve Verim Unsurlarının Belirlenmesi
}

\author{
Seyithan SEYDOŞOĞLU* \\ GAP Uluslar Arası Tarımsal Araştırma ve Eğitim Merkezi Müdürlüğ̈̈, Diyarbakır, TÜRKIYYE
}

\begin{abstract}
Geliș Tarihi/Received: 27.02.2014
Kabul Tarihi/Accepted: 25.08 .2014

*Sorumlu Yazar/Correspondence: ege_university47@hotmail.com

Özet: Araştırma, Diyarbakır ekolojik koșullarında bazı yaygın fiğ genotiplerinin verim ve verime etkili bazı öğelerin incelenmesi amacıyla, 2011-2013 yıllarında GAP Uluslararası Tarımsal Araştırma ve Eğitim Merkezi Müdürlüğü arazisinde yürütülmüsstür. Araştırmada toplam 20 farklı yaygın fiğ genotipi kullanılmış olup, tarla denemeleri tesadüf blokları deneme desenine göre 3 tekerrürlü olarak kurulmuştur. Araştırmada; yeşil ot verimi, kuru ot verimi ve tohum verimi ile birlikte, \% 50 çiçeklenmeye kadar geçen süre, bitki boyu, ana sap uzunluğu, ana sap sayısı, bitkide bakla sayısı, baklada tohum sayıs ve bin tane ağırlı̆̆ gibi bazı özellikler de incelenmiştir. Araştırmanın her iki yılında da; \% 50 çiçeklenmeye kadar geçen süre ve baklada tohum sayısı özellikleri hariç incelenen diğer tüm parametreler bakımından genotipler arasında istatistiki anlamda önemli farklılıklar belirlenmiştir. Araştırma sonucuna göre; genotiplerin, \% 50 çiçeklenmeye kadar geçen süre 157.8-174.0 gün, bitki boyu 33.9-62.6 cm, ana sap uzunluğu 52.0-83.3 cm, ana sap sayıs1 1.6-2.6 adet, bitkide bakla sayıs1 13.5-21.2 adet, baklada tohum sayıs1 4.7-5.6 adet, yeşil ot verimi 1522.0-3232.3 kg da ${ }^{-1}$, kuru ot verimi 308.0-919.5 kg da ${ }^{-1}$, tohum verimi 92.2-293.7 $\mathrm{kg} \mathrm{da}^{-1}$ ve bin tane ağırlığ 1 46.5-84.5 $\mathrm{g}$ arasında değişim gösterdiği saptanmıştır. Bu sonuçlara göre, Diyarbakır ili iklim ve toprak koşullarında; ot üretimi amacıyla "D-135" isimli yaygın fiğ genotipinin, tohum üretimi amacıyla ise "IFVS-715" ve "GAP-59998" yaygın fĭg genotiplerinin yetiştirilmesi önerilmiştir.
\end{abstract}

Anahtar Kelimeler: Yaygın fiğ, bitki boyu, kuru ot verimi, tohum verimi, 1000 tane ağırlığı

\section{Researches on Determination Yield and Yield Components of Some Common Vetch (Vicia sativa L.) Genotypes in Ecological Conditions of Diyarbakır}

\begin{abstract}
The research was conducted to determine yield and yield components of some common vetch genotypes in order to examine some of the traits, during 2011-2013 seasons in GAP International Agricultural Research and Training Center was carried out on the experimental field. In the study, a total of 20 different genotypes were used common vetch, field trials randomized block design with 3 replications was established. In the study, herbage yield, hay yield and seed yield in addition to days to $\% 50$ flowering duration, plant height, main stem length, main stem number, pod number per plant, grain number per pod as affecting yield some properties were also investigated. In both years of the study, days to $\% 50$ flowering duration and grain number per pod characteristics examined, except among genotypes for all other parameters are determined significant differences in statistical terms. According to the average of two years result; days to $\% 50$ flowering duration, plant height, main stem length, main stem number, pod number per plant, grain number per pod, herbage yield, hay yield, seed yield, 1000 seed weight were changed between $157.8-174.0$ days, 33.9-62.6 cm, 52.0-83.3 $\mathrm{cm}, 1.6-2.6$ number, 13.5-21.2 number, 4.7-5.6 number, $1522.0-3232.3 \mathrm{~kg} \mathrm{da}^{-1}, 308.0-919.5 \mathrm{~kg} \mathrm{da}^{-1}, 92.2-293.7 \mathrm{~kg} \mathrm{da}^{-1}, 46.5-84.5 \mathrm{~g}$, respectively. According to these results, under the climate and soil conditions of Diyarbakır; for the grass production common vetch genotypes "D-135" was suggested and for the seed production common vetch genotypes "IFVS-715" and "GAP-59998" were suggested.
\end{abstract}




\section{Giriş}

Güneydoğu Anadolu Bölgesi'nde sulanabilir tarım alanı gün geçtikçe artış göstermektedir. Sulu tarıma geçişle birlikte, bölgenin tarım alanlarında pamuk ve mısır gibi topraktan aşırı derecede besin maddesi kaldıran bitkilerin tarımı yoğunluk kazanmıştır. Bununla birlikte, yanlış sulama tekniklerinin kullanılması, bilinçsiz ve aşırı sulama ve gübreleme neticesinde toprakta tuzluluk ve alkalilik gibi sorunlar ortaya çıkmış, toprakların fiziksel ve kimyasal yapısı bozulmaya başlamıştır. $\mathrm{Bu}$ ve benzeri sorunların giderilmesi, toprakların adı geçen özellikleri yönünden iyileştirilmesi ve her şeyden daha önemlisi tarım topraklarının erozyona karşı korunması için, ana ürünleri etkilemeyecek şekilde, kışlık ara ürün tarımı olarak tek y1llık baklagil yem bitkilerinin gerek saf ve gerekse tek y1llık buğdaygillerle karışım şeklinde yetiştirilmesi, yörede büyük önem taşımaktadır. Bu durum aynı zamanda, kaba yem açı̆̆ının giderilmesi, toprağın organik madde ve azot yönünden zenginleştirilmesine de katk1 sağlayacaktır (Sağlamtimur ve ark., 1991; Aç1kgöz, 2001; Yücel ve ark., 2012).

Güneydoğu Anadolu Bölgesi’nde yem bitkisi ekilişlerinden ve bölgenin doğal çayır mera alanlarından elde edilen toplam kaba yem üretimi, bölgenin mevcut durumda sahip olduğu hayvan varlığının ancak \% 33.39'una yetecek kadardır. Bölgenin sahip olduğu mevcut hayvan varlığının sağlıklı beslenebilmesi için her türlü yem bitkilerinin yetiștirilmesi için elverișli bir ekolojiye sahip olan bölgede yem bitkileri tarımının geliştirilmesi büyük önem arz etmektedir (Sayar ve ark., 2010). Bu amaçla farklı iklim koşullarında yetişebilme ve geniş adaptasyon kabiliyetine sahip olan fiğler yöre tarımında önemli bir yere sahiptir.

Tarla tarımı içerisinde yer alabilecek yem bitkilerinin en önemlilerinden biri olan yaygın fiğ (Vicia sativa L.), dünyada 150 türü bulunan fiğ cinsine dâhil bir türdür (Tosun, 1974). Elçi ve Açıkgöz (1993)'e göre bu türlerden 59 adedi ülkemiz vejetasyonunda doğal olarak kendiliğinden yetişmektedir. Tarımı yapılan tür sayısı ise 14 kadardır. Hem otundan ve hem de tanesinden yararlanılabilen fĭ̆ bitkisi kısa vejetasyon süresine sahip, hemen her tip toprak ve iklim koşullarında yetişebilen, yem değeri yonca kadar yüksek olan ve hayvanlara yeşil ot olarak verildiğinde şişkinlik yapmayan bir yem bitkisidir. Protein içerikleri \% 20'nin üzerinde olan fiğ taneleri kırılarak kesif yem olarak da hayvanlara verilmektedir. Ayrıca, tane verimi için hasat edilen bitkilerden arta kalan samanı da iyi bir hayvan yemidir (Açıkgöz, 2001).
Bununla birlikte, diğer tarla ürünlerinde olduğu gibi fiğ bitkisinde de, birim alandan daha fazla verim elde etme amacıyla, üstün verimli yeni çeşit ya da hatların geliştirilmesi veya diğer ekolojilerde geliştirilenlerin yetiştirilmek istenen bölgedeki performanslarının belirlenmesi büyük önem taşımaktadır. Erzurum sulu koşullarında yapılan bir çalışmada (Çelik, 1980), farklı fiğ hat ve çeşitlerinin kuru ot verimlerinin 283.40-410.40 kg $\mathrm{da}^{-1}$ arasında değiştiği ve en yüksek kuru ot veriminin karaelçi çeşidinden alındığı; farklı fiğ çeşitleri ile İzmir koşullarında yürütülen bir çalışmada ise (Soya, 1987), ortalama yaş ot, kuru ot ve tohum verimlerinin sirasiyla 1345-1466, 282.8-316.6 ve 121.4-202.5 $\mathrm{kg} \mathrm{da}{ }^{-1}$ arasinda değiştiği saptanmıştır. Arslan ve Anlarsal (1996a ve 1996b)'ın Şanlıurfa koşullarında bazı adi fiğ çeşitlerinin yaş ve kuru ot verimlerinin sırasıyla 1685.93-2184.36 ve 296.99-386.92 $\mathrm{kg} \mathrm{da}{ }^{-1}$ arasında değiştiğini, aynı koşullarda söz konusu çeşitlerin ortalama tohum verimi ve 1000 tane ağırlıklarının ise $67.48-151.89 \mathrm{~kg} \mathrm{da}^{-1}$ ve 44.10 $56.94 \mathrm{~g}$ arasında değiştiğini bildirmektedir.

Yem bitkilerinde üretimin arttırılması için birim alandan elde edilen verimin arttırılması gerekmektedir. $\mathrm{Bu}$ ise, yüksek verim potansiyeline sahip iyi bir çeşit ve uygun yetiştirme tekniklerinin geliştirilmesi ile mümkün olacaktır. Bu çalışmanın amacı, Diyarbakır ekolojik koşullarına iyi uyum sağlayabilen bazı yaygın fiğ genotiplerinin ot ve tohum verimi ile verim unsurların belirlemektir.

\section{Materyal ve Yöntem}

Araştırmada; Suriye-Uluslararası Kurak Alanlarda Tarımsal Araştırma Merkezi (International Center for Agricultural Research in the Dry Areas, ICARDA) ve Doğu Akdeniz Tarımsal Araştırma Enstitüsü'nden temin edilen 5'er, Dicle Üniversitesi ve doğal floradan sağlanan 3'er, Uludağ Üniversitesi, Çukurova Üniversitesi, Tarla Bitkileri Merkez Araştırma Enstitüsü ve Ege Tarımsal Araştırma Enstitüsü'nden temin edilen 1 'er olmak üzere toplam 20 yaygın fiğ genotipi materyal olarak kullanılmıştır. Denemeler 20112012 ve 2012-2013 yıllarına ait yetiştirme sezonunda, Diyarbakır GAP Uluslararası Tarımsal Araştırma ve Eğitim Merkezi Müdürlüğü arazisinde yürütülmüştür.

Denemeler kurulmadan önce alınan toprakların bazı fiziksel ve kimyasal özellikleri Tablo 1'de verilmiştir. Tablo 1 incelendiğinde; araştırma yeri topraklarının killi-tınlı, tuzsuz, hafif alkali ve orta kireçli olduğu, toprakların organik madde içeriklerinin az, bitkiler tarafindan alınabilir fosfor kapsamının çok az, alınabilir potasyum 
bakımından ise yüksek seviyede olduğu belirlenmiştir.

Tablo 1. Araştırma alanına ait deneme öncesi alınan toprakların bazı fiziksel ve kimyasal analiz sonuçları

\begin{tabular}{llcc}
\hline \multirow{2}{*}{ Toprak özelliği } & \multirow{2}{*}{ Birim } & \multicolumn{2}{c}{ Değeri } \\
\cline { 3 - 4 } & & Killi-tınlı & Killi-tınlı \\
Bünye sınıfı & & 7.75 & 7.60 \\
& & 0.33 & 0.32 \\
$\mathrm{pH}$ & & 9.90 & 9.75 \\
Elektriksel iletkenlik & $\mathrm{dS} \mathrm{m}$ & (CL) \\
Kireç & $\%$ & 0.85 & 0.92 \\
Organik madde & $\%$ & 1.80 & 1.87 \\
Alınabilir fosfor & $\mathrm{kg} \mathrm{P}_{2} \mathrm{O}_{5} \mathrm{da}^{-1}$ & 180 & 220 \\
Alınabilir potasyum & $\mathrm{kg} \mathrm{K}_{2} \mathrm{O} \mathrm{da}^{-1}$ & 180
\end{tabular}

Diyarbakır İli genellikle Akdeniz ve Doğu Anadolu karasal ikliminin etkisi altında bulunmaktadır. Araştırmanın yürütüldüğü aylara ait Diyarbakır İlinin bazı iklim değerleri Tablo 2'de verilmiştir. 2011-2012 vejetasyon döneminde ortalama sıcaklık $10.3^{\circ} \mathrm{C}$, toplam yağış $487.2 \mathrm{~mm}$ ve ortalama nisbi nem \% 64 iken, 2012-2013 döneminde bu değerler sirasiyla $11.1{ }^{\circ} \mathrm{C}, 384.1$ $\mathrm{mm}$ ve \% 65 olmuştur. Uzun yıllar ortalamasına göre vejetasyon dönemindeki ortalama sicaklık $10.8^{\circ} \mathrm{C}$, toplam yağış ortalaması $453.6 \mathrm{~mm}$ ve ortalama nisbi nem \% 64 olarak gerçekleşmiştir (Anonim, 2012) (Tablo 2).

Tablo 2. Diyarbakır iline ait bazı iklim verileri (Anonim, 2012)

\begin{tabular}{|c|c|c|c|c|c|c|c|c|c|}
\hline \multirow[t]{2}{*}{ Aylar } & \multicolumn{3}{|c|}{ Ortalama sicaklik $\left({ }^{\circ} \mathrm{C}\right)$} & \multicolumn{3}{|c|}{ Yağış $(\mathrm{mm})$} & \multicolumn{3}{|c|}{ Nisbi nem (\%) } \\
\hline & $2011-2012$ & $2012-2013$ & $\begin{array}{l}\text { Uzun } \\
\text { Yillar }\end{array}$ & $2011-2012$ & $2012-2013$ & $\begin{array}{l}\text { Uzun } \\
\text { Yillar }\end{array}$ & 2011-2012 & $2012-2013$ & $\begin{array}{l}\text { Uzun } \\
\text { Yillar }\end{array}$ \\
\hline Kasim & 6.4 & 12.0 & 9.6 & 0.0 & 73.0 & 54.1 & 59 & 77 & 68 \\
\hline Aralık & 2.3 & 5.1 & 4.1 & 48.0 & 40.2 & 71.5 & 74 & 85 & 77 \\
\hline Ocak & 3.5 & 2.4 & 1.7 & 40.0 & 78.3 & 73.6 & 73 & 85 & 77 \\
\hline Şubat & 4.7 & 1.9 & 3.5 & 49.9 & 74.4 & 67.0 & 70 & 68 & 73 \\
\hline Mart & 9.0 & 5.1 & 8.2 & 46.6 & 44.0 & 67.9 & 56 & 60 & 66 \\
\hline Nisan & 13.0 & 15.2 & 13.8 & 209.0 & 26.2 & 70.5 & 76 & 59 & 63 \\
\hline Mayıs & 17.7 & 19.6 & 19.2 & 80.1 & 41.0 & 42.1 & 68 & 58 & 56 \\
\hline Haziran & 25.5 & 27.7 & 26,0 & 13.6 & 7.0 & 6.9 & 38 & 28 & 31 \\
\hline Ortalama/Toplam & 10.3 & 11.1 & 10.8 & 487.2 & 384.1 & 453.6 & 64 & 65 & 64 \\
\hline
\end{tabular}

Araştırmada denemeler, tesadüf blokları deneme desenine göre 3 tekrarlamalı olarak kurulmuştur. Parsellerde sıra arası $20 \mathrm{~cm}$, parsel ebad1 6 × 1.2 m olarak belirlenmiş olup, parsellerin yarısı ot, diğer yarısı ise tohum verimine ait parametrelerin ölçülmesine esas alınmıștır. Bitkiler her iki yılda da Kasım ayının sonunda ekilmiştir. Toprak analizi sonuçları da dikkate alınarak ekimle birlikte $3 \mathrm{~kg} \mathrm{da}{ }^{-1} \mathrm{~N}$ ve $6 \mathrm{~kg} \mathrm{da}{ }^{-1} \mathrm{P}_{2} \mathrm{O}_{5}$ olacak şekilde her parsele homojen olarak gübreleme yapılmıştır. Hasat sırasında, her parselin başından ve sonundan 0.5 m'lik kismı kenar tesiri olarak atıldıktan sonra geriye kalan $6 \mathrm{~m}^{2}$ lik parselin yarısı tam çiçeklenme döneminde ot ile ilgili gözlem ve ölçümler, kalan diğer yarısı ise fizyolojik olum döneminde tohum ile ilgili gözlem ve ölçümler için hasat edilmiştir. Buna göre, Mayıs ayının ortasinda (12/05/2012, 18/05/2013) ot verimi, haziran ayında (01/06/2012, 10/06/2013) ise tohum verimi için hasatlar gerçekleştirilmiştir.

Araştırmada ele alınan yaygın fiğ genotiplerine ilişkin; \% 50 çiçeklenmeye kadar geçen süre, bitki boyu, ana sap uzunluğu, ana sap sayısı, yeşil ve kuru ot verimi, bitkide bakla sayısı, baklada tohum sayısı, tohum verimi ve 1000 tane ağırlığ 1 gözlem/ölçümleri tespit edilmiştir (Tosun, 1974; Anonymous, 1976; Altın, 1991; Albayrak ve Töngel, 2003; Anonim, 2014).
Elde edilen verilerde her bir özellik için homojenlik testi yapılmış olup, varyanslar homojen çıkmış ve iki yılın birleştirilmiş verileri üzerinden Tesadüf Blokları Deneme Desenine göre varyans analizi yapılarak sonuçlar değerlendirilmiştir. Ortalamalar arasındaki farklılıklar LSD (Least Significant Difference) testi ile karşılaştırılmıştır (Yurtsever, 1984).

\section{Bulgular ve Tartışma}

Yaygın fĭ̆ genotiplerine ilişkin araştırmada incelenen parametrelere ait veriler ve ilgili istatistiki değerlendirmeler Tablo 3-7'de sunulmuştur.

\section{1. \% 50 çiçeklenmeye kadar geçen süre}

Çiçeklenmeye kadar geçen süre yönünden Tablo 3 incelendiğinde, iki yıllık ortalama verilerine göre genotipler ile yıllar arasında istatistiksel bakımdan çok önemli derecede farkl1lık görülmüştür. \% 50 çiçeklenmeye kadar geçen süre 2011 yılında genotiplerin ortalaması olarak 166.8 gün iken, 2012 yılında 160.3 gün olmuştur. İki yılın ortalama değerleri dikkate alındığında ise, \% 50 çiçeklenmeye kadar geçen süre sayıs1 157.8-174.0 gün arasında değiştiği, 6 nolu genotipin diğer genotiplere göre daha erkenci 
Tablo 3. Yaygın fiğ genotiplerinde \% 50 çiçeklenmeye kadar geçen süre ve bitki boyuna ilişkin ortalama değerler*

\begin{tabular}{|c|c|c|c|c|c|c|}
\hline \multirow[t]{2}{*}{ Genotipler } & \multicolumn{3}{|c|}{$\begin{array}{c}\text { \% } 50 \text { çiçeklenmeye kadar geçen } \\
\text { süre (gün) }\end{array}$} & \multicolumn{3}{|c|}{$\begin{array}{l}\text { Bitki boyu } \\
\text { (cm) }\end{array}$} \\
\hline & 2011 & 2012 & Ortalama & 2011 & 2012 & Ortalama \\
\hline 1-İFVS 3091 & 162.3 & 155.3 & $158.8 \mathrm{ij}$ & 53.7 & 39.8 & $46.7 \mathrm{~d}-\mathrm{f}$ \\
\hline 2-İFVS 2427 & 162.6 & 155.6 & $159.1 \mathrm{ij}$ & 56.1 & 41.2 & $48.6 \mathrm{~b}-\mathrm{e}$ \\
\hline 3-İFVS 715 & 162.6 & 156.6 & 159.61 & 54.8 & 46.8 & $50.8 \mathrm{~b}$ \\
\hline 4-İFVS 2541 & 163.3 & 156.3 & 159.81 & 54.6 & 44.2 & $49.4 \mathrm{~b}-\mathrm{d}$ \\
\hline 5-İFVS 3889 & 163.6 & 156.6 & $160.1 \mathrm{~h} 1$ & 52.6 & 42.4 & $47.5 \mathrm{c}-\mathrm{f}$ \\
\hline $6-\mathrm{D}-135$ & 161.3 & 154.3 & $157.8 \mathrm{j}$ & 61.8 & 56.5 & $59.1 \mathrm{a}$ \\
\hline 7-Kubilay-82 & 162.6 & 157.0 & 159.81 & 52.6 & 44.0 & $48.3 \mathrm{~b}-\mathrm{f}$ \\
\hline 8-Dicle & 170.3 & 163.3 & $166.8 \mathrm{~cd}$ & 53.8 & 42.1 & $48.0 \mathrm{~b}-\mathrm{f}$ \\
\hline 9-Alınoğlu 2001 & 168.6 & 161.6 & $165.1 \mathrm{ef}$ & 54.4 & 44.7 & $49.5 \mathrm{~b}-\mathrm{d}$ \\
\hline 10-Kralk1zı & 171.6 & 164.6 & $168.1 \mathrm{c}$ & 53.0 & 38.4 & 45.7 ef \\
\hline 11-Görkem & 169.0 & 162.0 & $165.5 \mathrm{~d}-\mathrm{f}$ & 54.0 & 45.4 & $49.7 \mathrm{~b}-\mathrm{d}$ \\
\hline 12-GATAEM-D-70-1 & 169.3 & 162.3 & $165.8 \mathrm{de}$ & 49.4 & 33.9 & $41.6 \mathrm{~g}$ \\
\hline 13-Adana-Hat-22 & 177.3 & 170.6 & $174.0 \mathrm{a}$ & 53.8 & 48.4 & $51.1 \mathrm{~b}$ \\
\hline 14-GATAEM-D-70-2 & 172.6 & 167.0 & $169.8 \mathrm{~b}$ & 51.5 & 50.0 & $50.7 \mathrm{~b}$ \\
\hline 15-Uludağ & 173.3 & 167.6 & $170.5 \mathrm{~b}$ & 49.5 & 44.9 & $47.2 \mathrm{c}-\mathrm{f}$ \\
\hline 16-Özveren & 167.3 & 161.3 & $164.3 \mathrm{f}$ & 55.8 & 44.5 & $50.2 \mathrm{bc}$ \\
\hline 17-GAP 2604 & 165.6 & 160.0 & $162.8 \mathrm{~g}$ & 62.6 & 57.1 & $59.8 \mathrm{a}$ \\
\hline 18-GAP 2490 & 165.0 & 158.0 & $161.5 \mathrm{gh}$ & 61.5 & 56.5 & $59.0 \mathrm{a}$ \\
\hline 19-GAP 61721 & 165.3 & 159.3 & $162.3 \mathrm{~g}$ & 55.4 & 42.9 & $49.1 \mathrm{~b}-\mathrm{d}$ \\
\hline 20-GAP 59998 & 161.6 & 156.6 & $159.1 \mathrm{ij}$ & 47.6 & 42.8 & $45.2 \mathrm{f}$ \\
\hline Ortalama & $166.8 \mathrm{~A}$ & $160.3 \mathrm{~B}$ & 163.5 & $54.4 \mathrm{~A}$ & $45.3 \mathrm{~B}$ & 49.9 \\
\hline CV (\%) & 0.8 & & & 5.4 & & \\
\hline $\mathrm{LSD}_{\text {(genotip) }}$ & 1.4 & & & 3.1 & & \\
\hline $\operatorname{LSD}_{(\mathrm{y} 1)}$ & 2.0 & & & 1.7 & & \\
\hline $\operatorname{LSD}_{\text {(genotip x y } 1 \text { ) }}$ & & & & 4.4 & & \\
\hline
\end{tabular}

olduğu belirlenmiştir (Tablo 3). Araştırmada, \% 50 çiçeklenmeye kadar geçen süre ile ilgili bu bulgular Sayar ve ark. (2011)'nın bulguları ile uyumlu iken, Yücel ve ark. (2005) ve Çil ve ark. (2006)'nın bulgularından daha yüksek çıkmıştır. $\mathrm{Bu}$ farklılık, araştırmanın yürütüldüğü alanın ekolojik özellikleri ile araştırmada ele alınan bitkisel materyalin genetik yapılarının farklı olmasından kaynaklanabilir. Bölgede yapılan genel gözlemlere göre, Diyarbakır ilinin iklimsel yapısından kaynaklı, hemen hemen tüm tarla ürünlerinde çiçeklenme ve tohum hasadı tarihi diğer illere göre yaklaşık iki hafta daha geç olmaktadır.

\subsection{Bitki boyu}

Tablo 3'ten görüleceği üzere; bitki boyu bakımından yaygın fiğ genotipleri ve yıllar arasındaki farklılıklar istatistiksel açıdan çok önemli bulunmuştur. Araştırmada ele alınan genotipler birbirini izleyen iki farklı y1lda farklı boylanmalar göstermiş, ikinci yılda ilk yıla göre daha düşük bitki boyu değerleri tespit edilmiştir. Araştırmanın ikinci yılında genotiplere ilişkin bitki boyu ortalamalarının daha kısa oluşu, yağış miktarının daha az (Tablo 2) olmasından kaynaklanmaktadır.

İki yıllık ortalama değerler dikkate alındığında ise; en yüksek bitki boyu $59.8 \mathrm{~cm}$ ile 17 nolu genotipten elde edilirken, bunu istatistiki olarak aynı grupta yer alan $6(59.1 \mathrm{~cm})$ ve $18(59.0 \mathrm{~cm})$ nolu genotipler izlemiştir. En düşük bitki boyu değeri ise $41.6 \mathrm{~cm}$ ile 12 nolu genotipte saptanmıştır. Genotiplerin ortalaması olarak bitki boyu değerlerinin y1llara göre 33.9-62.6 cm arasında değiştiği, en yüksek bitki boyu değeri her iki yılda da 17 nolu genotipten (sırasiyla 62.6 ve $57.1 \mathrm{~cm}$ ) elde edilirken, en düşük bitki boyu 2011 y1lında 20 nolu $(47.6 \mathrm{~cm}), 2012$ y1linda ise 12 nolu genotipten $(33.9 \mathrm{~cm})$ elde edilmiştir. Bunun sonucu olarak genotip $\mathrm{x}$ yıl interaksiyonu istatistiksel olarak çok önemli çıkmıştır (Şekil 1 ve Tablo 3). Bitki boyu ile ilgili elde edilen bu bulgular Şılbır ve Sağlamtimur (1991), Başbağ ve ark. (2001) ve Sayar ve ark. (2009)'nın bulgularıyla benzerlik göstermektedir. Kökten (2011) tarafindan Bingöl kuru şartlarında yürütülen araştırmada, incelenen hat ve çeşitlere göre değişmekle birlikte, yaygın fiğ hat ve çeşitlerinin ortalama bitki boyu $22.4 \mathrm{~cm}$ olarak belirlenmiştir. 


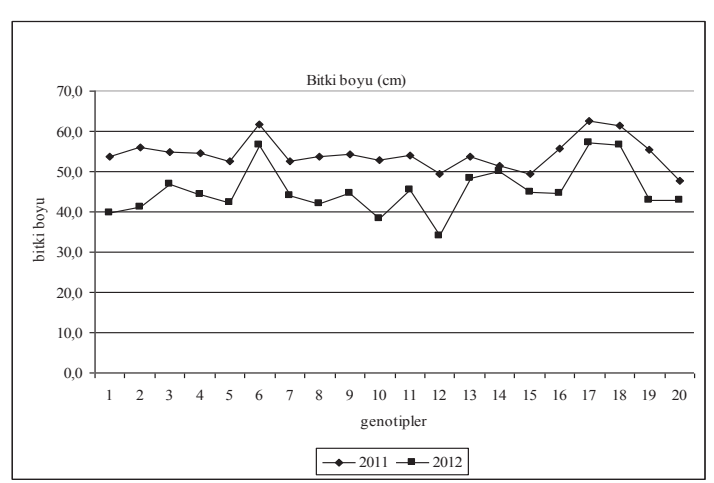

Şekil 1. Yaygın fiğ genotiplerinin bitki boyuna ilişkin genotip x y1l interaksiyonu

\subsection{Ana sap uzunluğu}

Ana sap uzunluğu yönünden yaygın fiğ genotipleri ve yıllar arasındaki farklılıklar istatistiksel açıdan çok önemli bulunmuştur. Genotiplerin ortalaması olarak, 2011 y1lında ana sap uzunluğu $67.6 \mathrm{~cm}$ iken, 2012 yılında $69.9 \mathrm{~cm}$ olarak saptanmıştır. İki yıllık ortalama değerler dikkate alındığında; en yüksek ana sap uzunluğu $78.8 \mathrm{~cm}$ ile 17 nolu genotipten elde edilirken, bunu aralarındaki farklılı̆̆ın istatistiksel olarak önemsiz olduğu 18 nolu genotip $(76.5 \mathrm{~cm})$ izlemiştir. En düşük ana sap uzunluğu ise $57.7 \mathrm{~cm}$ ile 12 nolu genotipten elde edilmiştir (Tablo 4).
Genotiplerin ana sap uzunluğuna 2011 ve 2012 yıllarında hüküm süren iklim değerlerinin etkisinin farklı olması, genotip $\mathrm{x}$ yıl interaksiyonunun istatistiksel olarak çok önemli çıkmasına neden olmuştur. Nitekim bazı genotiplerin ana sap uzunlukları ilk yıl daha uzun olurken, bazılarının ikinci yıl daha uzun olmuş, diğer bazı genotiplerin sap uzunlukları ise her iki yılda da birbirine çok yakın olmuştur. Buna göre; genotipler arasındaki ana sap uzunluğu değerleri yılların ortalaması olarak 52.0-83.3 cm arasında değişiklik göstermiş olup, 2011 yılında $81.9 \mathrm{~cm}$ ile 16 nolu genotip, 2012 yilında ise $83.3 \mathrm{~cm}$ ile 17 nolu genotip ana sap uzunluğu yönünden en yüksek değeri göstermiştir (Şekil 2 ve Tablo 4).

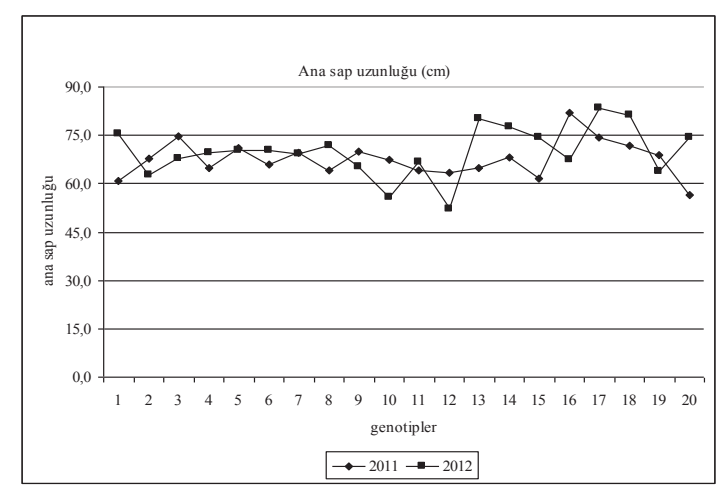

Şekil 2. Yaygın fiğ genotiplerinin ana sap uzunluğuna ilişkin genotip x yıl interaksiyonu

Tablo 4. Yaygın fiğ genotiplerinde ana sap uzunluğu ve ana sap sayısına ilişkin ortalama değerler*

\begin{tabular}{|c|c|c|c|c|c|c|}
\hline \multirow{2}{*}{ Genotipler } & \multicolumn{3}{|c|}{ Ana sap uzunluğu (cm) } & \multicolumn{3}{|c|}{ Ana sap sayıs1 (adet bitki ${ }^{-1}$ ) } \\
\hline & 2011 & 2012 & Ortalama & 2011 & 2012 & Ortalama \\
\hline 1-İFVS 3091 & 60.9 & 75.3 & $68.1 \mathrm{e}-\mathrm{h}$ & 1.9 & 2.4 & $2.2 \mathrm{ab}$ \\
\hline 2-İFVS 2427 & 67.9 & 62.7 & $65.3 \mathrm{~h} 1$ & 1.7 & 2.4 & $2.0 \mathrm{a}-\mathrm{c}$ \\
\hline 3-İFVS 715 & 74.8 & 67.9 & $71.3 \mathrm{c}-\mathrm{e}$ & 1.8 & 2.5 & $2.2 \mathrm{ab}$ \\
\hline 4-İFVS 2541 & 64.9 & 69.7 & $67.3 \mathrm{f}-\mathrm{h}$ & 1.6 & 2.4 & $2.0 \mathrm{a}-\mathrm{c}$ \\
\hline 5-İFVS 3889 & 70.9 & 70.3 & $70.6 \mathrm{~d}-\mathrm{f}$ & 1.9 & 2.5 & $2.2 \mathrm{ab}$ \\
\hline $6-\mathrm{D}-135$ & 66.0 & 70.3 & $68.1 \mathrm{e}-\mathrm{h}$ & 1.9 & 2.4 & $2.1 \mathrm{a}-\mathrm{c}$ \\
\hline 7-Kubilay-82 & 69.6 & 69.2 & $69.4 \mathrm{~d}-\mathrm{g}$ & 1.8 & 2.2 & $2.0 \mathrm{a}-\mathrm{c}$ \\
\hline 8-Dicle & 64.3 & 71.8 & $68.1 \mathrm{e}-\mathrm{h}$ & 2.0 & 2.2 & $2.1 \mathrm{a}-\mathrm{c}$ \\
\hline 9-Alınoğlu 2001 & 70.1 & 65.2 & $67.6 \mathrm{e}-\mathrm{h}$ & 1.7 & 2.3 & $2.0 \mathrm{a}-\mathrm{c}$ \\
\hline 10-Kralk1z1 & 67.5 & 55.6 & 61.61 & 1.8 & 2.6 & $2.2 \mathrm{a}$ \\
\hline 11-Görkem & 64.3 & 66.5 & 65.4 h1 & 1.7 & 2.1 & $1.9 \mathrm{a}-\mathrm{c}$ \\
\hline 12-GATAEM-D-70-1 & 63.4 & 52.0 & $57.7 \mathrm{j}$ & 1.8 & 2.4 & $2.1 \mathrm{a}-\mathrm{c}$ \\
\hline 13-Adana-Hat-22 & 64.9 & 80.3 & $72.6 \mathrm{~cd}$ & 2.1 & 1.7 & 1.9 a-c \\
\hline 14-GATAEM-D-70-2 & 68.3 & 77.6 & $73.0 \mathrm{~b}-\mathrm{d}$ & 1.9 & 1.8 & $1.8 \mathrm{bc}$ \\
\hline 15-Uludağ & 61.6 & 74.3 & 67.9 e-h & 1.7 & 2.0 & $1.9 \mathrm{a}-\mathrm{c}$ \\
\hline 16-Özveren & 81.9 & 67.5 & $74.7 \mathrm{bc}$ & 1.9 & 1.7 & $1.8 \mathrm{c}$ \\
\hline 17-GAP 2604 & 74.3 & 83.3 & $78.8 \mathrm{a}$ & 1.8 & 2.0 & $1.9 \mathrm{a}-\mathrm{c}$ \\
\hline 18-GAP 2490 & 71.9 & 81.2 & $76.5 \mathrm{ab}$ & 1.8 & 2.5 & $2.2 \mathrm{ab}$ \\
\hline 19-GAP 61721 & 68.7 & 63.9 & $66.3 \mathrm{gh}$ & 1.9 & 2.0 & $1.9 \mathrm{a}-\mathrm{c}$ \\
\hline 20-GAP 59998 & 56.4 & 74.5 & $65.4 \mathrm{~h}$ & 1.7 & 2.3 & $2.0 \mathrm{a}-\mathrm{c}$ \\
\hline Ortalama & $67.6 \mathrm{~B}$ & $69.9 \mathrm{~A}$ & 68.8 & $1.8 \mathrm{~B}$ & $2.2 \mathrm{~A}$ & 2.0 \\
\hline CV (\%) & 4.9 & & & 14.4 & & \\
\hline $\mathrm{LSD}_{\text {(genotip) }}$ & $3.8_{(0.01)}$ & & & $0.3_{(0.05)}$ & & \\
\hline $\operatorname{LSD}_{(\mathrm{y} 1 \mathrm{l})}$ & $1.8_{(0.01)}$ & & & $0.3_{(0.05)}$ & & \\
\hline $\mathrm{LSD}_{\text {(genotip x yll) }}$ & $5.4_{(0.01)}$ & & & $0.4_{(0.05)}$ & & \\
\hline
\end{tabular}

*: Aynı grup içinde aynı harfle gösterilen ortalamalar arasında 0.05 veya 0.01 olasılıkla farklılık yoktur 
Araştırmamızda elde edilen ana sap uzunluğu ile ilgili bulgular Sayar ve ark. (2009) ve Çil ve ark. (2006)'nın bulguları ile paralellik göstermektedir.

\subsection{Ana sap sayısı}

Ana sap sayısı özelliği bakımından, araştırmada ele alınan 20 farklı yaygın fiğ genotipleri ve yıllar arasinda istatistiksel olarak önemli derecede farklılıklar bulunmuştur. Genotiplerin ortalaması olarak 2011 yılında ortalama ana sap sayıs1 1.8 adet bitki ${ }^{-1}$ iken, bu değer 2012 yılında ortalama 2.2 adet bitki ${ }^{-1}$ olarak tespit edilmiştir. İki yılın ortalama sonuçlarına göre; en yüksek ana sap sayısı 2.2 adet bitki ${ }^{-1}$ ile 10 nolu genotipten elde edilirken, bu değer ile, 14 ve 16 nolu genotipler hariç, diğer tüm genotiplerin ana sap sayısı değerleri arasındaki farklılık istatistiksel açıdan önemsiz çıkmıştır. Araştırmada ana sap sayısı yönünden genotip $x \quad y 11$ interaksiyonu istatistiksel olarak önemli çıkmış olup, çeşit ve genotipler iki farklı yılda farklı değerler göstermiştir (Şekil 3 ve Tablo 4).

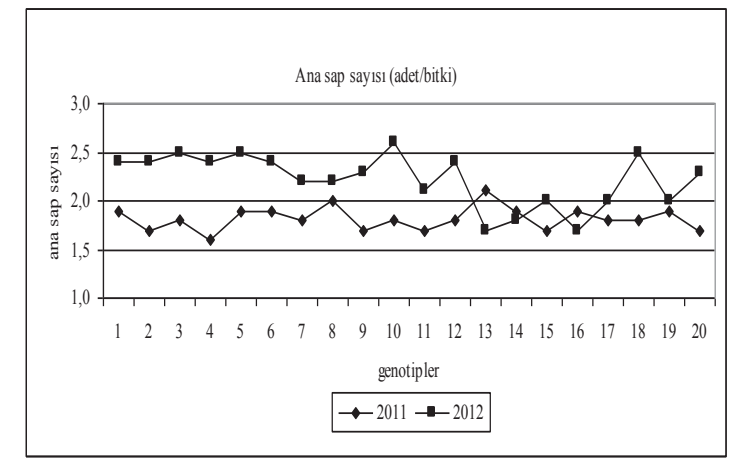

Şekil 3. Yaygın fiğ genotiplerinin ana sap sayısına ilişkin genotip x yıl interaksiyonu

\subsection{Yeşil ot verimi}

Yaygın fiğ genotiplerine ait yeşil ot verimi sonuçları incelendiğinde (Tablo 5); genotipler arasındaki farklılık istatistiksel açıdan çok önemli, y1llar arasındaki farklılık ise önemli bulunmuştur. İki yıllık ortalama değerler dikkate alındığında; en yüksek yeşil ot verimi $2791.0 \mathrm{~kg} \mathrm{da}^{-1}$ ile 6 nolu genotipten elde edilirken, bunu istatistiki olarak aralarındaki farklılığın önemsiz olduğu 3, 1 ve 4

Tablo 5. Yaygın fiğ genotiplerinde yeşil ot ve kuru ot verimlerine ilişkin ortalama değerler*

\begin{tabular}{|c|c|c|c|c|c|c|}
\hline \multirow{2}{*}{ Genotipler } & \multicolumn{3}{|c|}{ Yeşil ot verimi $\left(\mathrm{kg} \mathrm{da}^{-1}\right)$} & \multicolumn{3}{|c|}{ Kuru ot verimi $\left(\mathrm{kg} \mathrm{da}^{-1}\right)$} \\
\hline & 2011 & 2012 & Ortalama & 2011 & 2012 & Ortalama \\
\hline 1-İFVS 3091 & 3232.3 & 1968.3 & $2600.3 \mathrm{a}-\mathrm{c}$ & 790.6 & 468.5 & $629.5 \mathrm{bc}$ \\
\hline 2-İFVS 2427 & 3202.0 & 1736.7 & $2469.3 \mathrm{~b}-\mathrm{e}$ & 789.2 & 423.6 & $606.4 \mathrm{~cd}$ \\
\hline 3-İFVS 715 & 3068.0 & 2243.3 & $2655.7 \mathrm{ab}$ & 775.0 & 536.7 & $655.8 \mathrm{~b}$ \\
\hline 4-İFVS 2541 & 2978.0 & 2216.7 & $2597.3 \mathrm{a}-\mathrm{c}$ & 746.1 & 536.3 & $641.2 \mathrm{bc}$ \\
\hline 5-İFVS 3889 & 2900.0 & 2057.7 & $2478.8 \mathrm{~b}-\mathrm{e}$ & 733.4 & 496.1 & $614.7 \mathrm{~b}-\mathrm{d}$ \\
\hline $6-\mathrm{D}-135$ & 2867.0 & 2715.0 & $2791.0 \mathrm{a}$ & 701.7 & 712.3 & $707.0 \mathrm{a}$ \\
\hline 7-Kubilay-82 & 2805.0 & 1922.3 & $2363.7 \mathrm{~d}-\mathrm{g}$ & 740.5 & 489.0 & $614.7 \mathrm{~b}-\mathrm{d}$ \\
\hline 8-Dicle & 2783.0 & 2060.0 & $2421.5 \mathrm{c}-\mathrm{f}$ & 706.4 & 495.0 & $600.7 \mathrm{c}-\mathrm{e}$ \\
\hline 9-Alınoğlu 2001 & 2747.0 & 2330.3 & $2538.7 \mathrm{~b}-\mathrm{d}$ & 715.3 & 574.3 & $644.8 \mathrm{bc}$ \\
\hline 10-Kralk1zı & 2709.0 & 1823.7 & $2266.3 \mathrm{fg}$ & 703.3 & 443.8 & $573.6 \mathrm{~d}-\mathrm{f}$ \\
\hline 11-Görkem & 2704.0 & 2334.7 & $2519.3 \mathrm{~b}-\mathrm{d}$ & 713.3 & 582.1 & $647.7 \mathrm{bc}$ \\
\hline 12-GATAEM-D-70-1 & 2475.0 & 1620.0 & $2047.5 \mathrm{~h}-\mathrm{j}$ & 608.3 & 363.3 & $485.8 \mathrm{~h} 1$ \\
\hline 13-Adana-Hat-22 & 2451.0 & 2241.7 & $2346.3 \mathrm{~d}-\mathrm{g}$ & 589.0 & 559.6 & $574.3 \mathrm{~d}-\mathrm{f}$ \\
\hline 14-GATAEM-D-70-2 & 2417.0 & 2155.7 & $2286.3 \mathrm{e}-\mathrm{g}$ & 570.4 & 535.5 & $553.0 \mathrm{e}-\mathrm{g}$ \\
\hline 15-Uludağ & 2286.0 & 2153.3 & $2219.7 \mathrm{gh}$ & 543.8 & 522.6 & $533.2 \mathrm{f}-\mathrm{h}$ \\
\hline 16-Özveren & 2281.0 & 2116.7 & 2198.8 g-1 & 531.0 & 519.3 & $525.2 \mathrm{gh}$ \\
\hline 17-GAP 2604 & 2149.0 & 2895.0 & $2522.0 \mathrm{~b}-\mathrm{d}$ & 512.3 & 706.9 & $609.6 \mathrm{~b}-\mathrm{d}$ \\
\hline 18-GAP 2490 & 1612.0 & 2425.0 & $2018.5 \mathrm{ij}$ & 358.6 & 561.8 & 460.21 \\
\hline 19-GAP 61721 & 1524.0 & 2214.7 & $1869.3 \mathrm{j}$ & 350.6 & 530.8 & 440.71 \\
\hline 20-GAP 59998 & 1522.0 & 2423.3 & $1972.7 \mathrm{j}$ & 350.3 & 598.3 & 474.31 \\
\hline Ortalama & $2535.6 \mathrm{~A}$ & $2182.7 \mathrm{~B}$ & 2359.2 & $626.5 \mathrm{~A}$ & $532.8 \mathrm{~B}$ & 590.8 \\
\hline $\mathrm{CV}(\%)$ & 7.4 & & & 7.17 & & \\
\hline $\mathrm{LSD}_{\text {(genotip) }}$ & $199.3_{(0.01)}$ & & & $47.8_{(0.01)}$ & & \\
\hline $\mathrm{LSD}_{(\mathrm{y} 1 \mathrm{l})}$ & $318.9_{(0.05)}$ & & & $72.9_{(0.01)}$ & & \\
\hline $\mathrm{LSD}_{\text {(genotip } \mathrm{x} \text { yll) }}$ & $281.8_{(0.01)}$ & & & $67.6_{(0.01)}$ & & \\
\hline
\end{tabular}

nolu genotiplerin yeşil ot verimleri (sırasıyla 2655.7, 2600.3 ve $2597.3 \mathrm{~kg} \mathrm{da}^{-1}$ ) izlemiştir. İki yılın ortalama en düşük yeşil ot verimi $1869.3 \mathrm{~kg}$ $\mathrm{da}^{-1}$ ile 19 nolu genotipten elde edilmiş, $12,18 \mathrm{ve}$ 20 nolu genotipler de düşük verimli gruplar içerisinde yer almıștır (Tablo 5). Araştırmada yeșil ot verimi ile ilgili elde edilen bulgular, Arslan ve Anlarsal (1996a), Başbağ ve ark. (2001) ve Sayar ve ark. (2011)'nın bulgularıyla paralellik göstermiştir. 2011 yılında en yüksek yeşil ot 
verimi, 1 nolu genotipten (3232.3 $\left.\mathrm{kg} \mathrm{da}^{-1}\right)$ elde edilmiş, 2012 yılında ise $2895.0 \mathrm{~kg} \mathrm{da}^{-1}$ ile $17 \mathrm{nolu}$ genotipten sağlanmıştır. Yıllar itibariyle çeşit ve genotiplerin yeşil ot verimi yönünden -iklimsel farklılıktan kaynaklandığı düşünülen- bu farklı performanslar1 neticesinde genotip $\mathrm{x}$ y1l interaksiyonu istatistiksel açıdan çok önemli bulunmuştur (Şekil 4).

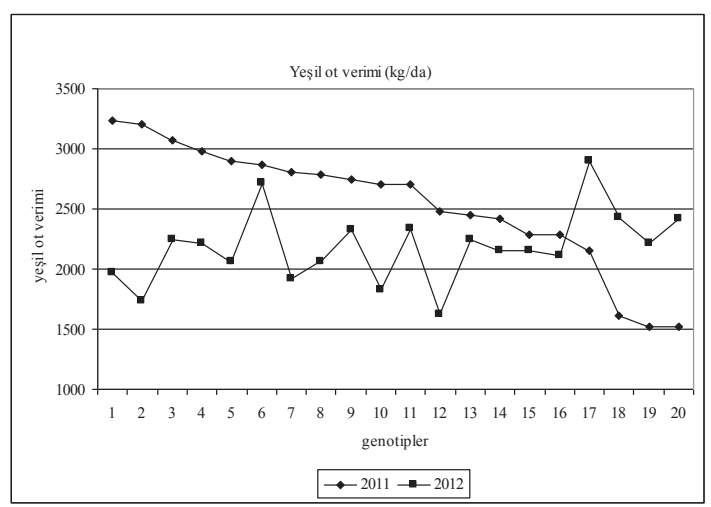

Şekil 4. Yaygın fiğ genotiplerinin yeşil ot verimine ilişkin genotip x yıl interaksiyonu

Genotipler arasındaki bu verim farklılıklarının çeşit özelliği ve genotiplerin uyum kabiliyetlerinin farklı olmasından kaynaklanabileceği bir çok araştırma sonuçlarında da vurgulanmıştır (Gökkuş ve ark., 1996; Bakoğlu ve Memiş, 2002; Kökten, 2011).

\subsection{Kuru ot verimi}

Yaygın fiğ genotiplerine ait iki yıllık kuru ot verimleri incelendiğinde (Tablo 5), araştırma konusu olan genotiplerin kuru ot verimi ortalamaları, y1llar ve genotip x y1l interaksiyonu ortalamaları arasındaki farklılık istatistiksel olarak çok önemli bulunmuştur. İki yılın ortalama kuru ot verimi sonuçlarına göre, en yüksek verim $707.0 \mathrm{~kg}$ $\mathrm{da}^{-1}$ ile 6 nolu genotipten elde edilmiştir. En düşük kuru ot verimi ise 19, 18, 20 ve 12 nolu genotiplerden (sirasiyla 440.7, 460.2, 474.3 ve $485.8 \mathrm{~kg} \mathrm{da}^{-1}$ ) elde edilmiştir. Genotip $\mathrm{x}$ y1l interaksiyonu incelendiğinde (Şekil 5), kuru ot

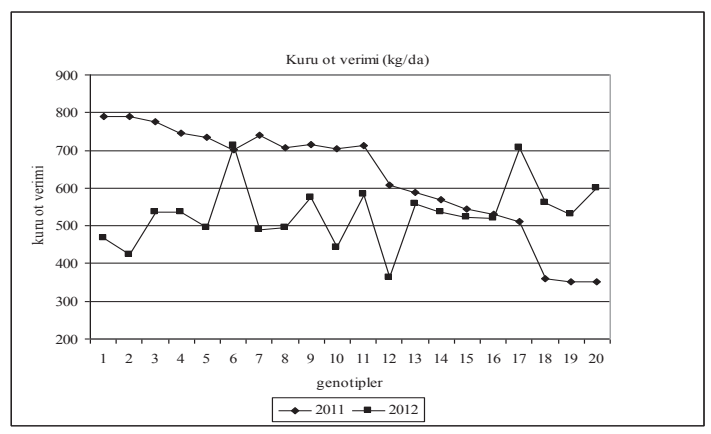

Şekil 5. Yaygın fiğ genotiplerinin kuru ot verimine ilişkin genotip x yıl interaksiyonu verimi değerlerinin 350.3-790.6 $\mathrm{kg} \mathrm{da}^{-1}$ arasında değiştiği, en yüksek kuru ot verimi 2011 yılında 1 nolu genotipten elde edilirken, 2012 y1lında ise $712.3 \mathrm{~kg} \mathrm{da}^{-1}$ ile 6 nolu genotipten elde edilmiştir. Araştırmada elde edilen kuru ot verimi ile ilgili bulgular, Çil ve ark. (2006), Mihailoviç ve ark. (2006), Sayar ve ark. (2009, 2011)'nın bulgularıla benzerlik göstermiştir.

\subsection{Bitkide bakla sayısı}

Bitkide bakla sayısı bakımından genotipler ve y1llar arasında istatistiksel olarak önemli farklılıklar olduğu belirlenmiştir. Araştırma yerinin iklim özelliklerinden genotiplerin farklı şekilde etkilenmeleri sonucu genotip x y1l interaksiyonu da önemli çıkmıştır. Nitekim Tablo 6'nın incelenmesinden de görüleceği üzere; bazı genotipler ilk y1l, bazıları ikinci y1l daha fazla baklaya sahip olurken, diğer bazı genotiplerin bakla sayıları ise her iki yılda da çok yakın değerler göstermiştir (Şekil 6).

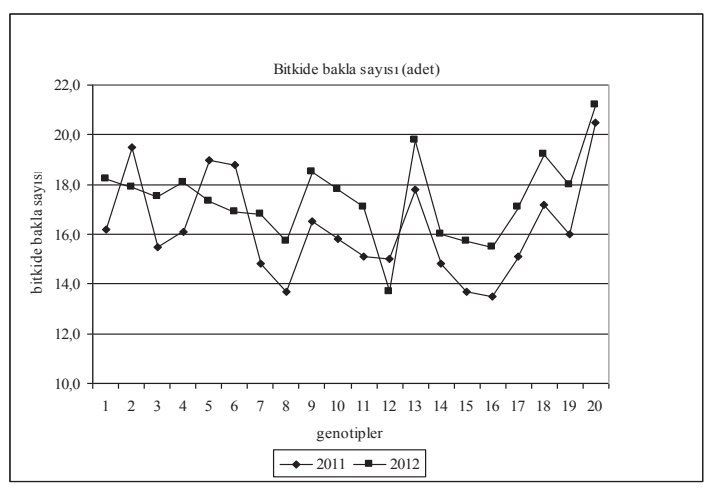

Şekil 6. Yaygın fiğ genotiplerinin bitkide bakla sayısına ilişkin genotip x yıl interaksiyonu

İki yıllık bakla sayısı ortalamalarına göre, en yüksek değer 20.8 adet ile 20 nolu genotipten elde edilirken, en düşük bakla sayısı 14.3 adet ile 12 nolu genotipten elde edilmiştir. Bununla birlikte 15,8 ve 16 nolu genotipler de düşük bakla sayısı gösteren grup içerisinde yer almıştır (Tablo 6).

\subsection{Baklada tohum sayısı}

Tablo 6 incelendiğinde; baklada tohum sayısı bakımından yıllar arasında istatistiki olarak önemli farklılık görülürken, genotiplerin ortalama değerleri arasındaki farklılık ile genotip $\mathrm{x}$ y1 interaksiyonu ise önemsiz bulunmuştur. Bununla birlikte, araştırmada genotiplerin baklada tohum sayısı değerleri 4.1-6.2 arasında değişiklik göstermiştir. Yaygın fiğde baklada tane sayısının 2.80-7.91 arasında değiştiği (Elçi ve Orak, 1991; Bucak ve Anlarsal, 1996; Y1lmaz ve Can, 1998; Başbağ ve ark., 1999) bildirilmektedir. 
Tablo 6. Yaygın fiğ genotiplerinde bitkide bakla ve baklada tohum sayısına ilişkin ortalama değerler*

\begin{tabular}{|c|c|c|c|c|c|c|}
\hline \multirow{2}{*}{ Genotipler } & \multicolumn{3}{|c|}{ Bitkide bakla sayısı (adet) } & \multicolumn{3}{|c|}{ Baklada tohum sayısı (adet) } \\
\hline & 2011 & 2012 & Ortalama & 2011 & 2012 & Ortalama \\
\hline 1-İFVS 3091 & 16.2 & 18.2 & $17.2 \mathrm{~d}-\mathrm{f}$ & 4.3 & 5.9 & 5.1 \\
\hline 2-İFVS 2427 & 19.5 & 17.9 & $18.7 \mathrm{~b}$ & 4.3 & 5.8 & 5.1 \\
\hline 3-İFVS 715 & 15.5 & 17.5 & $16.5 \mathrm{f}-\mathrm{h}$ & 4.7 & 4.9 & 4.8 \\
\hline 4-İFVS 2541 & 16.1 & 18.1 & $17.1 \mathrm{~d}-\mathrm{f}$ & 4.6 & 5.8 & 5.2 \\
\hline 5-İFVS 3889 & 19.0 & 17.3 & $18.2 \mathrm{bc}$ & 4.6 & 5.4 & 5.0 \\
\hline $6-\mathrm{D}-135$ & 18.8 & 16.9 & $17.9 \mathrm{~b}-\mathrm{d}$ & 4.5 & 5.4 & 4.9 \\
\hline 7-Kubilay-82 & 14.8 & 16.8 & $15.8 \mathrm{~h} 1$ & 5.2 & 5.9 & 5.6 \\
\hline 8-Dicle & 13.7 & 15.7 & $14.7 \mathrm{jk}$ & 5.1 & 5.2 & 5.1 \\
\hline 9-Alınoğlu 2001 & 16.5 & 18.5 & $17.5 \mathrm{c}-\mathrm{e}$ & 4.7 & 5.4 & 5.0 \\
\hline 10-Kralk1zı & 15.8 & 17.8 & $16.8 \mathrm{e}-\mathrm{g}$ & 4.4 & 5.2 & 4.8 \\
\hline 11-Görkem & 15.1 & 17.1 & $16.1 \mathrm{~g}-1$ & 5.0 & 5.1 & 5.1 \\
\hline 12-GATAEM-D-70-1 & 15.0 & 13.7 & $14.3 \mathrm{k}$ & 4.1 & 5.6 & 4.9 \\
\hline 13-Adana-Hat-22 & 17.8 & 19.8 & $18.8 \mathrm{~b}$ & 4.2 & 5.5 & 4.8 \\
\hline 14-GATAEM-D-70-2 & 14.8 & 16.0 & $15.4 \mathrm{ij}$ & 5.3 & 5.4 & 5.4 \\
\hline 15-Uludağ & 13.7 & 15.7 & $14.7 \mathrm{jk}$ & 4.9 & 5.9 & 5.4 \\
\hline 16-Özveren & 13.5 & 15.5 & $14.5 \mathrm{jk}$ & 4.9 & 5.9 & 5.4 \\
\hline 17-GAP 2604 & 15.1 & 17.1 & $16.1 \mathrm{~g}-1$ & 4.7 & 5.9 & 5.3 \\
\hline 18-GAP 2490 & 17.2 & 19.2 & $18.2 \mathrm{bc}$ & 4.7 & 5.9 & 5.3 \\
\hline 19-GAP 61721 & 16.0 & 18.0 & $17.0 \mathrm{~d}-\mathrm{g}$ & 4.6 & 6.2 & 5.4 \\
\hline 20-GAP 59998 & 20.5 & 21.2 & $20.8 \mathrm{a}$ & 4.3 & 5.5 & 4.9 \\
\hline Ortalama & $16.2 \mathrm{~B}$ & $17.4 \mathrm{~A}$ & 16.8 & $4.7 \mathrm{~B}$ & $5.6 \mathrm{~A}$ & 5.1 \\
\hline$\overline{\mathrm{CV}}(\%)$ & 4.9 & & & 12.3 & & \\
\hline $\mathrm{LSD}_{\text {(genotip) }}$ & 1.0 & & & & & \\
\hline $\operatorname{LSD}_{(\mathrm{y} 1 \mathrm{l})}$ & 0.7 & & & 0.8 & & \\
\hline $\operatorname{LSD}_{\text {(genotip x yll) }}$ & 1.4 & & & & & \\
\hline
\end{tabular}

Yılların ortalamasına bakıldı̆̆ında; 2011 yılında baklada tohum sayısı 4.7 adet iken, 2012 yılında ise 5.6 adet olarak saptanmıştır (Tablo 6). Yıllar arasındaki bu farklılığa, araştırmanın ilk yılındaki yağış miktarının (Tablo 2) etkili olduğu düşünülmektedir. Albayrak ve ark. (2005), yaygın fiğ genotiplerinde baklada tane sayısının düşük olduğu lokasyonlarda, tohum bağlama dönemindeki yüksek yağışların bakla içerisindeki tohumun gelişimini olumsuz yönde etkileyerek tohum oranını düşürdüğünü bildirmektedirler.

\subsection{Tohum verimi}

Tablo 7 incelendiğinde; genotipler ile yıllar arasında istatistiksel olarak çok önemli farklılıklar belirlenirken, tohum verimi yönünden genotip x y1l interaksiyonu da çok önemli çıkmıştır. Genotiplerin ortalama tohum verimleri, araştırmanın ikinci yılında ilk yıla göre daha düşük olmuş, genotiplerin ortalaması olarak 2011 yılında ortalama tohum verimi $220.4 \mathrm{~kg} \mathrm{da}^{-1}$ iken, 2012 y1lında ise $165.5 \mathrm{~kg} \mathrm{da}^{-1}$ olarak saptanmıştır (Tablo 7). $\mathrm{Bu}$ durum, bitkilerde çiçeklenmenin, döllenmenin ve dolayısıyla baklaların oluşmaya başladığı özellikle Mayıs ayındaki kurak koşulların (Tablo 2) olumsuz etkilerinden kaynaklandığ düşünülmektedir. Nitekim, kuraklığın çiçeklenme, tohum oluşumu ve gelişimini olumsuz yönde etkilediği (Manga, 1991), vejetasyon süresinin kısalmasıyla birlikte bitkilerin daha az fotosentez ürünlerini üreteceği ve dane dolumunun daha zayıf olacağı (Kırtok, 1980) bildirilmektedir. Baklagil yem bitkilerinde suya en fazla ihtiyaç duyulduğu dönemin çiçeklenme başlangıcı ile tane oluşum devresi arasında olduğu, bu dönemden sonra bitkinin su ihtiyacı karşılansa bile verimin düşük olacağ1 bildirilmiştir (Tosun, 1974). Karadağ ve Büyükburç (2002) da benzer duruma vurgu yapmışlardır.

Araştırmanın yürütüldüğü yıllar arasındaki sıcaklık ortalamaları farklılığından dolayı yıllara göre farklı genotipler tohum verimi yönünden farklı performanslar göstermiştir. En yüksek tohum verimi; 2011 yilında $293.7 \mathrm{~kg} \mathrm{da}^{-1}$ ile 3 nolu genotipte, 2012 y1lında ise $217.0 \mathrm{~kg} \mathrm{da}^{-1}$ ile 20 nolu genotipte belirlenmiştir. $\mathrm{Bu}$ durumun sonucu olarak genotip x y1l interaksiyonu istatistiksel açıdan çok önemli çıkmıştır (Şekil 7 ve Tablo 7).

İki yıllık ortalama değerler dikkate alındığında; en yüksek tohum verimi $242.0 \mathrm{~kg} \mathrm{da}^{-1}$ ile 3 nolu genotipten elde edilirken, bunu istatistiki olarak aynı grupta yer alan 20 nolu (241.3 $\left.\mathrm{kg} \mathrm{da}^{-1}\right)$ genotip izlemiştir. Bununla birlikte, 3, 20, 1, 2, 5, 6 ve 19 nolu genotipler arasında tohum verimi yönünden istatistiksel anlamda farklılık bulunmamıştır. En düşük ortalama tohum verimi ise $124.6 \mathrm{~kg} \mathrm{da}^{-1}$ ile 12 nolu genotipten elde edilmiş olup, 14 nolu genotipin verimi de düşük grupta yer almıştır (Tablo 7). Araştırmada tohum 
verimi ile ilgili bu bulgular Yücel ve ark. (2005) ve Çil ve ark. (2006)'nın bulgularıyla paralellik göstermiştir.

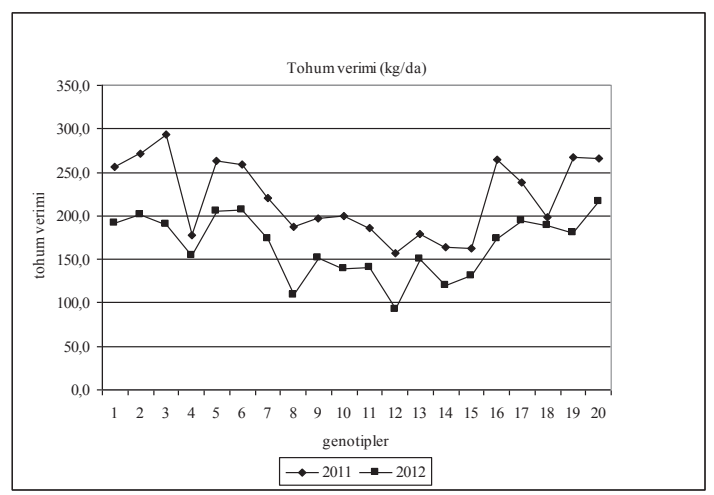

Şekil 7. Yaygın fiğ genotiplerinin tohum verimine ilişkin genotip x yıl interaksiyonu

\subsection{0 tane ağırlığı}

1000 tane ağırlığ̣ yönünden araştırmada incelenen 20 farklı yaygın fiğ genotipleri, yıllar ve genotip x yıl interaksiyonu arasında istatistiksel olarak çok önemli derecede faklılıklar tespit edilmiştir. Genotiplerin ortalaması olarak, 2011 yılında 1000 tane ağırlığ $69.3 \mathrm{~g}$ iken, 2012 yılında $58.6 \mathrm{~g}$ olarak saptanmıştır. İki yıllık ortalama değerlere göre; en yüksek 1000 tane ağırlığı 75.3 g ile 1 nolu genotipten elde edilirken, bunu istatistiki olarak aynı grupta yer alan 6 nolu genotip (74.1 g) izlemiştir. En düşük ortalama 1000 tane ağırlığı ise $50.0 \mathrm{~g}$ ile 14 nolu genotipten elde edilmiş olup, 11 nolu genotip ile aralarındaki farklılık istatistiksel açıdan önemsiz bulunmuştur. Genotip $x$ yıl interaksiyonu incelendiğinde ise; 1000 tane ağırlı̆̆ 1 değerlerinin 46.5-84.5 g arasında değiştiğii, en yüksek 1000 tane ağırlığı 2011 yılında 6 nolu genotipten $(84.5 \mathrm{~g})$ elde edilirken, 2012 y1lında 20 nolu genotipten $(67.2 \mathrm{~g}$ ) elde edilmiştir (Şekil 8 ve Tablo 7). Araştırmada elde edilen 1000 tane ağırlığı ile ilgili bulgular; Büyükburç ve ark. (2003), Karadağ ve Büyükburç (2004), Tamkoç ve Avc1 (2004) ve Sayar ve ark. (2011)'nın bulgularıyla benzerlik göstermiştir.

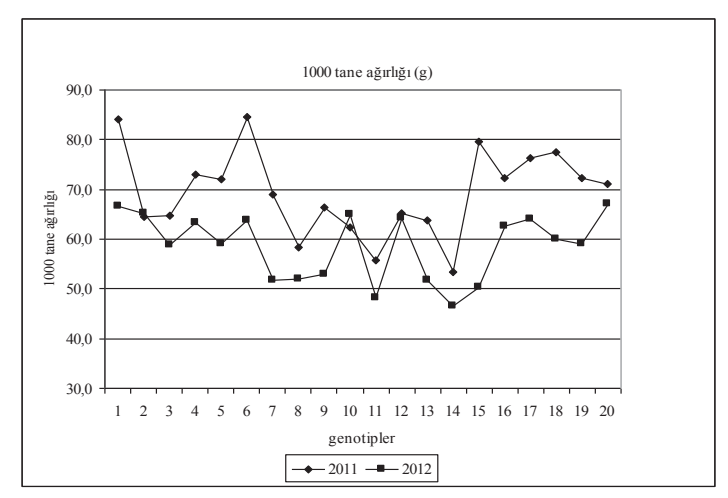

Şekil 8. Yaygın fiğ genotiplerinin 1000 tane ağırlığına ilişkin genotip x yıl interaksiyonu

Tablo 7. Yaygın fiğ genotiplerinde tohum verimi ve 1000 tane ağırlığına ilişkin ortalama değerler*

\begin{tabular}{|c|c|c|c|c|c|c|}
\hline \multirow{2}{*}{ Genotipler } & \multicolumn{3}{|c|}{ Tohum verimi $\left(\mathrm{kg} \mathrm{da}^{-1}\right)$} & \multicolumn{3}{|c|}{1000 tane ağırlığı $(\mathrm{g})$} \\
\hline & 2011 & 2012 & Ortalama & 2011 & 2012 & Ortalama \\
\hline 1-İFVS 3091 & 255.8 & 192.2 & $224.0 \mathrm{ab}$ & 84.1 & 66.5 & $75.3 \mathrm{a}$ \\
\hline 2-İFVS 2427 & 270.8 & 201.1 & $235.9 \mathrm{ab}$ & 64.4 & 65.3 & $64.9 \mathrm{~d}-\mathrm{f}$ \\
\hline 3-İFVS 715 & 293.7 & 190.2 & $242.0 \mathrm{a}$ & 64.8 & 58.8 & $61.8 \mathrm{f}-\mathrm{h}$ \\
\hline 4-İFVS 2541 & 177.9 & 154.2 & $166.1 \mathrm{ef}$ & 73.1 & 63.3 & $68.2 \mathrm{~b}-\mathrm{d}$ \\
\hline 5-İFVS 3889 & 263.3 & 205.0 & $234.2 \mathrm{ab}$ & 72.0 & 59.1 & $65.5 \mathrm{c}-\mathrm{f}$ \\
\hline $6-\mathrm{D}-135$ & 259.3 & 206.9 & $233.1 \mathrm{ab}$ & 84.5 & 63.7 & $74.1 \mathrm{a}$ \\
\hline 7-Kubilay-82 & 220.6 & 174.3 & $197.5 \mathrm{~cd}$ & 68.9 & 51.7 & $60.3 \mathrm{~g}-1$ \\
\hline 8-Dicle & 186.9 & 108.5 & $147.7 \mathrm{fg}$ & 58.4 & 52.0 & $55.2 \mathrm{jk}$ \\
\hline 9-Alınoğlu 2001 & 196.7 & 151.2 & $173.9 \mathrm{e}$ & 66.3 & 52.8 & 59.6 h1 \\
\hline 10-Kralk1z1 & 199.2 & 138.5 & $168.9 \mathrm{e}$ & 62.3 & 65.0 & $63.6 \mathrm{e}-\mathrm{g}$ \\
\hline 11-Görkem & 186.4 & 140.6 & $163.5 \mathrm{ef}$ & 55.7 & 48.3 & $52.0 \mathrm{kl}$ \\
\hline 12-GATAEM-D-70-1 & 157.1 & 92.2 & $124.6 \mathrm{~h}$ & 65.1 & 64.2 & $64.6 \mathrm{~d}-\mathrm{f}$ \\
\hline 13-Adana-Hat-22 & 179.0 & 150.5 & 164.7 ef & 63.7 & 51.7 & $57.7 \mathrm{ij}$ \\
\hline 14-GATAEM-D-70-2 & 163.3 & 120.1 & $141.7 \mathrm{gh}$ & 53.5 & 46.5 & 50.01 \\
\hline 15-Uludağ & 162.9 & 130.8 & $146.9 \mathrm{fg}$ & 79.5 & 50.3 & $64.9 \mathrm{~d}-\mathrm{f}$ \\
\hline 16-Özveren & 264.3 & 173.6 & $219.0 \mathrm{~b}$ & 72.3 & 62.7 & $67.5 \mathrm{~b}-\mathrm{d}$ \\
\hline 17-GAP 2604 & 238.7 & 194.6 & $216.6 \mathrm{bc}$ & 76.3 & 63.9 & $70.1 \mathrm{~b}$ \\
\hline 18-GAP 2490 & 198.4 & 188.4 & $193.4 \mathrm{~d}$ & 77.5 & 60.0 & $68.8 \mathrm{bc}$ \\
\hline 19-GAP 61721 & 267.3 & 180.7 & $224.0 \mathrm{ab}$ & 72.2 & 59.1 & $65.6 \mathrm{c}-\mathrm{e}$ \\
\hline 20-GAP 59998 & 265.6 & 217.0 & $241.3 \mathrm{a}$ & 71.0 & 67.2 & $69.1 \mathrm{bc}$ \\
\hline Ortalama & $220.4 \mathrm{~A}$ & $165.5 \mathrm{~B}$ & 192.9 & $69.3 \mathrm{~A}$ & $58.6 \mathrm{~B}$ & 63.9 \\
\hline CV (\%) & 8.7 & & & 5.2 & & \\
\hline $\mathrm{LSD}_{\text {(genotip) }}$ & 19.3 & & & 3.8 & & \\
\hline $\operatorname{LSD}_{(\mathrm{y} 1 \mathrm{l})}$ & 24.4 & & & 2.4 & & \\
\hline $\mathrm{LSD}_{\text {(genotip x yil) }}$ & 27.4 & & & 5.4 & & \\
\hline
\end{tabular}




\section{Sonuçlar}

Diyarbakır ekolojik şartlarına uygun yaygın fiğ genotiplerinin belirlenmesi amaciyla 20 farklı yaygın fĭg genotipleriyle yürütülen bu çalışmada; iki y1llık verilere göre, hem yeşil ve hem de kuru ot verimleri birlikte dikkate alındığında 6 nolu "D135 " yaygın fiğ genotipinin yüksek verimli olduğu görülmektedir. Bununla birlikte, bazı y1llar bir miktar kuru ot veriminden feragat edildiği takdirde 1,3 ve 4 nolu genotiplerinin de yeşil ot verimi yönünden yüksek verim sağladığı saptanmıştır.

Diğer genotiplere göre daha erkenci olan " $\mathrm{D}$ 135" genotipi aynı zamanda yüksek boylu genotipler arasında yer almıştır. 17 ve 18 nolu genotipler bitki boyu ve ana sap uzunluğu yönünden de avantajlı durumdadır. Öte yandan, ana sap sayısı ve bitkide bakla sayısı bakımından sırasıyla 10 ve 20 nolu genotiplerin öne çıktı̆̆ 1 belirlenmiştir. Baklada tohum sayısı yönünden ise genotipler arasında farklılık bulunmamıștır. Tohum verimi bakımından ise 3 ve 20 nolu "IFVS 715" ve "GAP 59998" genotiplerinin öne çıktığı görülmüştür.

$\mathrm{Bu}$ araştırma sonucuna göre, Diyarbakır ili iklim ve toprak koşullarında tarla tarımı içerisinde özellikle kışlık ara ürün olarak yaygın fiğ yetiştiriciliğinin iyi sonuçlar vereceği belirlenmiştir. Bu anlamda fiğ bitkisi; hem baklagil bitkisi olmasından dolayı kendisinden sonra gelecek ürüne iyi bir toprak yapısı bırakacak, hem de ot veya tohum amaciyla ekilmek suretiyle yöre çiftçisine ek gelir kaynağı teşkil edecektir. Aynı zamanda, verime yönelik çalışmalarda farklı genotiplerin tescil edilmesi ve yapilacak islah çalışmalarında kullanılmak üzere genetik stokların bulundurulması büyük önem arz etmektedir.

Sonuç olarak, Diyarbakır ili iklim ve toprak koşullarında, ot üretimi amacıyla D-135, tohum üretimi için ise, IFVS 715 ve GAP 59998 isimli yaygın fiğ genotiplerinin yetiştirilmesi önerilebilir.

\section{Kaynaklar}

Açıkgöz, E., 2001. Yem Bitkileri. Uludağ Üniversitesi Güçlendirme Vakfi Yay. No:182, Bursa.

Albayrak, S., Töngel, M.Ö., 2003. Fiğ hatlarının Samsun koşullarına adaptasyonu. Türkiye 5. Tarla Bitkileri Kongresi, 13-17 Ekim, Diyarbakır, s. 326-330.

Albayrak, S., Töngel, Ö., Güler, M., 2005. Orta Karadeniz Bölgesinde çeşit adayı fiğ (Vicia sativa L.)'lerin tohum verimi ve verim öğelerinin belirlenmesi ve stabilite analizi. Ondokuz Mayls Üniversitesi Ziraat Fakültesi Dergisi, 20(1): 50-55.

Altın, M., 1991. Yem Bitkileri Yetiştirme Tekniği (Yem Bitkileri Tarımı). Trakya Üniversitesi Tekirdağ Ziraat Fakültesi, Yayın No:114, Ders Kitab1 No:3, Tekirdağ.
Anonim, 2012. Meteoroloji Bölge Müdürlüğü kayıtları, Diyarbakır.

Anonim, 2014. Tarımsal Değerleri Ölçme Denemeleri Teknik Talimat, Fiğ Türleri (Vicia L. species)-2001. Tarım ve Köyişleri Bakanlığı Tohumluk Tescil ve Sertifikasyon Merkezi Müdürlüğü, http://www.tarim.gov.tr/Sayfalar/PageNotFoundErro r.aspx?requestUrl=http://www.tarim.gov.tr/BUGEM /TTSM/TR/dosya/1-9897/h/01 fig.pdf (Erişim tarihi: 28.06.2014).

Anonymous, 1976. Seed Science and Technology. Vol: 3, (I.S.T.A.).

Arslan, A., Anlarsal, A.E., 1996a. Güneydoğu Anadolu Bölgesi koşullarında farklı tohumluk miktarlarının bazı adi fiğ (Vicia sativa L.) çeşitlerinde ot verimi ve bazı özelliklere etkisi üzerinde bir araștırma. Türkiye 3. Çayır-Mer'a ve Yembitkileri Kongresi, 17-19 Haziran, Erzurum, s. 640-647.

Arslan, A., Anlarsal, A.E., 1996b. Güneydoğu Anadolu Bölgesi koşullarında farklı tohumluk miktarlarının bazı adi fiğ (Vicia sativa L.) çeşitlerinde tohum verimi ve bazı özelliklere etkisi üzerinde bir araştırma. Türkiye 3. Çayır-Mer'a ve Yembitkileri Kongresi, 17-19 Haziran, Erzurum, s. 632-639.

Bakoğlu, A., Memiş, A., 2002. Farklı oranlarda ekilen adi fiğ (Vicia sativa L.) ve arpa (Hordeum vulgare L.) karışımlarında tohum verimi ve bazı özelliklerin belirlenmesi, Firat Üniversitesi Fen ve Mühendislik Bilimleri Dergisi, 14(1): 29-35.

Başbağ, M., Peker, C., Gül, İ., 1999. Diyarbakır sulu koşullarında farklı sıra arası ve tohumluk miktarının adi fiğ de tohum verimi ve bazı verim kriterlerine etkisi üzerine bir araştırma. Türkiye 3. Tarla Bitkileri Kongresi, 15-18 Kasim, Adana, s. 218-222.

Başbağ, M., Saruhan, V., Gül, İ., 2001. Diyarbakır koşullarında bazı tek yıllık baklagil yem bitkilerinin adaptasyonu üzerine bir araştırma. Türkiye 4. Tarla Bitkileri Kongresi, 17-21 Eylül, Tekirdağ, s.169173.

Bucak, B., Anlarsal, A.E., 1996. Cukurova florasından toplanan iki fiğ türü (Vicia sativa ve Vicia villosa) populasyonundan seçilen hatlarda morfolojik ve sitolojik araştırmalar. Türkiye 3. Çayır-Mera ve Yem Bitkileri Kongresi, 17-19 Haziran, Erzurum, s. 239245

Büyükburç, U., İptaş, S., Karadağ, Y., Acar, A.A., 2003. Tokat-Kozova koşullarında kışlık ekilen bazı adi fiğ (Vicia sativa L.) hat ve çeșitlerinin tohum verimi ve bazı verim karakterlerinin belirlenmesi. Türkiye 5.Tarla Bitkileri Kongresi, 13-17 Ekim, Diyarbakır, s. 357-362.

Çelik, N., 1980. Erzurum kıraç koşullarında farklı sıra aralıkları ve biçim çağları ile kimyevi gübrelerin adi fiğ (Vicia sativa L. var. L 147)'nn kuru ot ve tane verimleri ile otun kalitesine etkileri üzerinde araştırmalar. Doktora tezi, Atatürk Üniversitesi Fen Bilimleri Enstitüsü, Tarla Bitkileri Ana Bilim Dalı, Erzurum.

Çil, A., Çil, A.N., Yücel, C., 2006. Bazı adi fiğ (Vicia sativa L.) hatlarının Harran Ovası koşullarında 
adaptasyonu. Harran Üniversitesi Ziraat Fakültesi Dergisi, 10(1/2): 53-61.

Elçi, S., Açıkgöz, E., 1993. Baklagil ve buğdaygil yem bitkileri tanıtma kılavuzu. TİGEM, Avşaroğlu Matbaas1, Ankara.

Elçi, Ş., Orak, A., 1991. Tekirdağ koşullarında adapte olabilecek adi fiğ hatlarının belirlenmesine ilişkin bir araştırma. Türkiye 2. Çayır-Mera ve Yem Bitkileri Kongresi, 28-31 Mayıs, İzmir, s. 540-551.

Gökkuş, A., Bakoğlu, A., Koç, A., 1996. Bazı adi fiğ (Vicia sativa L.) hat ve çeşitlerinin Erzurum sulu şartlarına adaptasyonu üzerine bir çalışma. Türkiye 3. Çayır-Mera ve Yembitkileri Kongresi, 17-19 Haziran, Erzurum, s. 675-678.

Karadağ, Y., Büyükburç, U., 2002. Çemende (Trigonella foenum graecum L.) farkl1 ekim zamanlarının ot ve tohum verimlerine etkisi üzerinde bir araştırma. Gaziosmanpaşa Üniversitesi Ziraat Fakültesi Dergisi, 19(1): 97-102.

Karadağ, Y., Büyükburç, U., 2004. Tokat-Kazova koşullarında farklı tohumluk miktarlarının bazı adi fiğ (Vicia sativa L.) çeşitlerinde ot ve tohum verimine etkisi. Tarım Bilimleri Dergisi, 10(2): 149157.

Kırtok, Y., 1980. Çukurova'nın taban ve kıraç koşullarında ekim zamanı, azot miktarı ve ekim sıklığının iki arpa çeşidinin verim ve verim unsurlarına etkileri üzerinde araştırmalar. Doçentlik tezi, Çukurova Üniversitesi Ziraat Fakültesi, Tarla Bitkileri Bölümü, Adana.

Kökten, K., 2011. Bingöl ekolojik koşullarında bazı adi fiğ (Vicia sativa L.) hat ve çeşitlerinde tohum verimi ve bazı tarımsal özelliklerin belirlenmesi. Bingöl Üniversitesi Fen Bilimleri Dergisi, 1(2): 1-5.

Manga, İ., 1991. Yembitkilerinde tohumluk üretiminde karşılaşılan sorunlar. Türkiye 2. Çayır-Mer'a ve Yembitkileri Kongresi, 28-31 May1s, İzmir, s. 472482.

Mihailoviç, V., Mikiç, A., Çupina, B., Katiç, S., Karagiç, D., Pataki, I., Eriç, P., 2006. Yield and forage yield components in winter vetch cultivars. Grassland Science in Europe, 11: 255-257.

Sağlamtimur, T., Tükel, T., Gülcan, H., Anlarsal, A.E., Tans1, V., 1991. GAP bölgesinde yem bitkileri yetiştirme olanaklar1. Türkiye 2. Çayır Mera Yem Bitkileri Kongresi, 28-31 Mayıs, İzmir, s. 213-223.

Sayar, M.S., Anlarsal A.E., Başbağ, M., 2010. Güneydoğu Anadolu Bölgesinde yem bitkileri tarımının mevcut durumu sorunları ve çözüm önerileri. Harran Üniversitesi Ziraat Fakültesi Dergisi, 14(2): 59-67.

Sayar, M.S., Karahan, H., Başbağ, M., 2011. Kızıltepe ekolojik koşullarında bazı adi fiğ (Vicia sativa L.) genotiplerinin verim ve verim unsurları ile özellikler aras1 ilișkilerin belirlenmesi. GAP VI. Tarım Kongresi, 09-12 Mayıs, Şanlıurfa, s. 663-669.

Sayar, M.S., Yücel, C., Tekdal, S., Yasak, M.Ş., Yıldız, E., 2009. Diyarbakır koşullarında bazı adi fiğ (Vicia sativa L.) hatlarının verim ve verim unsurlarının belirlenmesi. Türkiye VIII. Tarla Bitkileri Kongresi, 19-22 Ekim, Hatay, s. 518-522.

Soya, H., 1987. Ege bölgesi kıyı kesimi yerel adi fĭ̆ (Vicia sativa L.) çeşitlerinde sıra arası mesafesi ve tohumluk miktarının verim ve verim karakterlerine etkisi. Ege Üniversitesi Ziraat Fakültesi Dergisi, 24(2): 91-103.

Şılbır, Y., Sağlamtimur, T., 1991. Harran ovası kıraç koşullarına uygun fiğ (Vicia sativa L.) çeşitlerinin saptanması. Çukurova Üniversitesi Ziraat Fakültesi Dergisi, 6(3): 155-166.

Tamkoç, A., Avcı, M.A., 2004. Doğadan seçilen adi fiğ (Vicia sativa L.) hatlarında bazı tarımsal karakterlerin belirlenmesi. Selçuk Üniversitesi Ziraat Fakültesi Dergisi, 18(34): 11-121.

Tosun, F., 1974. Baklagil ve Buğdaygil Yem Bitkileri Kültürü. Atatürk Üniversitesi Ziraat Fakültesi Yayınları No: 242, Ders Kitapları Serisi No: 8, Erzurum.

Yılmaz, Ş., Can, E., 1998. Hatay koşullarında yetiştirilen bazı adi fiğ çeşit ve hatlarında tane verimi ve verimi etkileyen özellikler arası ilişkiler. Mustafa Kemal Paşa Üniversitesi Ziraat Fakültesi Dergisi, 3(2): 13126.

Yurtsever, N., 1984. Deneysel İstatistik Metotları. Köy Hizmetleri Genel Müdürlüğü Yayınları, Genel Yayın No: 121, Ankara.

Yücel, C., Avcı, M. Anlarsal, A.E., 2005. Bazı adi fĭ̆ (Vicia sativa L.) hat ve çeşitlerinin Çukurova taban koşullarında tane verimi ve verimle ilgili özelliklerinin saptanmas1. Çukurova Üniversitesi Ziraat Fakültesi Dergisi, 20(3): 99-108.

Yücel, C., Sayar, M.S., Yücel, H., 2012. Diyarbakır koşullarında yaygın fiğ (Vicia sativa L.) genotiplerinin ot kalitesi ile ilgili bazı özelliklerin saptanmasi. Harran Tarlm ve Gida Bilimleri Dergisi, 16(2): 45-54. 